\title{
RELATIONSHIP BETWEEN PREGNANT WOMEN'S HIGH- RISK AGE WITH THE PRETERM OF LABOR IN BIDAN PRAKTIK MANDIRI (BPM) BIDAN NANIK SUWATI, AMD. KEB, PUNGGING VILLAGE, MOJOSARI SUB-DISTRICT, MOJOKERTO DISTRICT
}

\author{
Siti Fithrotul Umami ${ }^{1}$, Titiek Idayanti ${ }^{2}$ \\ ${ }^{1}$ Ar-Rahma Midwifery Academy \\ ${ }^{2}$ STIKES Dian Husada Mojokerto \\ *Correspondence: \\ Siti Fithrotul Umami \\ Email: vividfaradisa1@gmail.com
}

\begin{abstract}
Background: High-risk age for pregnant women is $<20$ or $>35$ years, the possibility of a bad pregnancy/ complications will increase, such as preterm labor. Premature birth is the main cause in almost $2 / 3$ of births. Preterm labor is a labor that occurs in pregnancy between 28 - 37 weeks. The incidence in BPM Bidan Nanik Suwati, Pungging Village, Mojosari Sub-District, which is from 80 women giving birth, found 7 respondents experienced preterm labor including $4(57.14 \%)$ aged $<20$ and $>35$ years and $3(42.86 \%)$ aged $20-30$ years. Objectives: The purpose of this study was to determine the correlation between pregnant women's high-risk age with the preterm of labor in Bidan Praktik Mandiri (BPM) Bidan Nanik Suwati, Amd. Keb, Pungging Village, Mojosari Sub-District, Mojokerto District.

Method: The research method used is analytic correlation with a case control approach using research instruments in the form of secondary data. The sample technique used in this study was total sampling, so the sample of the study was all pregnant women of high-risk age in BPM Nanik Suwati, Pungging Village, Mojosari Sub-District at 68 respondents. The results of data collection were processed by chisquare statistical test $\left(\mathrm{X}^{2}\right)$ with a significance distance of $\alpha=0.05$.

Results: From the results of the study, almost half (31\%) of respondents experienced preterm labor and most (69\%) of respondents experienced term delivery. Shows a significant relationship between the age of high-risk pregnant women with the incidence of preterm labor with a value of $\mathrm{P}=0.036$.

Conclusion: The factors that influence preterm labor, such as parity, frequency of ANC patients, and obstetric complications. Therefore, it should be recommended for mothers as much as possible not to become pregnant at a high-risk age, namely age $<20$ and $>35$ years.
\end{abstract}

Key words: High Risk Age, Pregnant Women, Preterm Labor Incidence.

\section{INTRODUCTION}

The age of pregnant women is very influential in labor. The age of high risk of the possibility of a bad pregnancy / complications will increase, such as miscarriage, preterm labor, susceptibility to infection, anemia of pregnancy, hypertension, diabetes mellitus, and obesity. Age less than 20 years or over 35 years has a greater risk for preterm delivery (low birth weight) compared to 20-30 years old or with low parity. The age of healthy reproduction is known that the safe age for pregnancy in labor is 20-30 years. Maternal mortality in pregnant and childbirth women under the age of 20 years is 2-5 times higher than maternal deaths that occur at the age of 20-29 years and experience a rise again after 30-35 years of age (Wiknjosastro, 2005).

Preterm birth is a major cause in almost $2 / 3$ of infant deaths. Babies born prematurely do not have adequate growth and development to make adjustments that are not difficult for 
intra-uterine life, and prospect to damage the ability to survive and have good health (Jensen, 2000). Preterm labor is a labor that occurs in pregnancy less than or equal to 37 weeks (between 28 - 37 weeks) or with a fetal body weight less than 2500 grams. Several factors can cause preterm labor, including general conditions (age, parity, marital status, low socioeconomic conditions, anemia and malnutrition, as well as poor activity patterns), maternal diseases that accompany pregnancy, and obstetric complications. Of the several factors that cause preterm labor, one is reproductive status. This reproductive status factor occurs from age, parity, and marital status.

Estimates of childbirth in Indonesia each year around 5 million people can be explained that the infant mortality rate is 56 per 10,000 to 280,000 or occurs every $18-20$ minutes. The cause of infant mortality is neonatal asphyxia 46-60\%, infections $23-34 \%$, prematurity / low birth weight $15-20 \%$, labor trauma $2-7 \%$ and congenital defects $1-3 \%$. Based on data from BPM Nanik Suwati found that there were 80 mothers giving birth. Of the 80 number of mothers giving birth there were $7(8.75 \%)$ mothers who gave birth prematurely and 73 $(91.25 \%)$ mothers gave birth at term. Preterm birth mothers 7 people including 4 (57.14\%) preterm mothers aged $<20$ and $>35$ years and 3 (42.86\%) mothers who experienced 20-30 years of preterm labor.

The purpose of this study was to determine the correlation between pregnant women's high-risk age with the preterm of labor in Bidan Praktik Mandiri (BPM) Bidan Nanik Suwati, Amd. Keb, Pungging Village, Mojosari SubDistrict, Mojokerto District.

\section{METHODS}

Study Design

The research design used is analytic design which aims to test hypotheses about the possibility of causal relationships between variables. This study uses a case control research design. The independent variable in this study is the age of high-risk pregnant women. The dependent variable in this study was the incidence of preterm labor.

\section{Setting}

This research was conducted in Bidan Praktik Mandiri (BPM) Bidan Nanik Suwati,
Amd. Keb, Pungging Village, Mojosari SubDistrict, Mojokerto District

\section{Research Subject}

The population in this study were all pregnant women of high-risk age who met the inclusion criteria recorded in the register book at Bidan Praktik Mandiri (BPM) Bidan Nanik Suwati, Amd. Keb, Pungging Village, Mojosari Sub-District, Mojokerto District totaling 68 people. To determine the sample size in this study using a total sampling population. The sample in this study were all pregnant women of high-risk age who were recorded in the register book as many as 68 people in Bidan Praktik Mandiri (BPM) Bidan Nanik Suwati, Amd. Keb, Pungging Village, Mojosari SubDistrict, Mojokerto District.

\section{Instrument}

The instruments used were past labor records, and a history of pregnancy control which included a history of pregnancy exercises, as well as a record of the process of the preterm labor.

\section{Data Analysis}

The results of this study were analyzed using the Chi Square Statistical Test with value of $\alpha=0.05$.

\section{RESULTS}

\section{Characteristics of Respondents}

Table 1. Characteristics of Respondent in Bidan Praktik Mandiri (BPM) Bidan Nanik Suwati, Amd. Keb, Pungging Village, Mojosari Sub-District, Mojokerto District $(\mathrm{n}=68)$.

\begin{tabular}{lcc}
\hline Characteristics of Respondent & Frequency (f) & Percentage (\%) \\
\hline Occupational Status & & \\
$\quad$ Work & 18 & 26 \\
$\quad$ Does not Work & 50 & 74 \\
Parity & 61 & 90 \\
$1-4$ & 7 & 10 \\
$>4$ & & \\
ANC Frequency & 48 & 71 \\
$1-3$ & 20 & 29 \\
$>3$ & & 1.5 \\
Accompanying Disease & 1 & 98.5 \\
$\quad$ Accompanying Disease & 67 & 1.5 \\
No Accompanying Disease & & 98.5 \\
Obstetric Complications & 1 & \\
Obstetric Complications & 67 & 31 \\
No Obstetric Complications & & 69 \\
Preterm Labor & 21 & \\
Premature & 47 & \\
Aterm & &
\end{tabular}

Sources: Primary Data 
Distribution of Respondents based on HighRisk Age of Pregnant Women in The Incidence of Preterm Labor

Table 2. Distribution of Respondents based on High-Risk Age of Pregnant Women in The Incidence of Preterm Labor in Bidan Praktik Mandiri (BPM) Bidan Nanik Suwati, Amd. Keb, Pungging Village, Mojosari Sub-District, Mojokerto District $(n=68)$.

\begin{tabular}{lcc}
\hline \multirow{2}{*}{$\begin{array}{l}\text { Incidence of } \\
\text { Preterm Labor }\end{array}$} & $\begin{array}{c}\text { High-Risk Age of Pregnant Women } \\
(<\mathbf{2 0} \text { dan }>\mathbf{3 5} \text { years })\end{array}$ \\
\cline { 2 - 3 } & Frequency (f) & Percentage (\%) \\
\hline Premature & 21 & 31 \\
Aterm & 47 & 69 \\
\hline Total & 68 & 100 \\
\hline Sources: Primary Data & &
\end{tabular}

Sources: Primary Data

Based on table 2, almost half $(31 \%)$ of respondents experienced preterm labor and most $(69 \%)$ of respondents who experienced aterm labor.

Distribution of Respondents based on Parity in The Incidence of Preterm Labor

Table 3. Distribution of Respondent based on Parity in The Incidence of Preterm Labor in Bidan Praktik Mandiri (BPM) Bidan Nanik Suwati, Amd. Keb, Pungging Village, Mojosari Sub-District, Mojokerto District $(\mathrm{n}=68)$.

\begin{tabular}{ccccccc}
\hline \multirow{2}{*}{ Parity } & \multicolumn{3}{c}{ Incidence of Preterm Labor } & \multicolumn{2}{c}{ Total } \\
\cline { 2 - 5 } & \multicolumn{2}{c}{ Premature } & \multicolumn{2}{c}{ Aterm } & & \\
\cline { 2 - 6 } & $(\mathrm{f})$ & $(\%)$ & $(\mathrm{f})$ & $(\%)$ & $(\mathrm{f})$ & $(\%)$ \\
\hline $1-4$ & 18 & 26.47 & 43 & 63.24 & 61 & 89.71 \\
$>4$ & 3 & 4.41 & 4 & 5.88 & 7 & 10.29 \\
\hline Total & 21 & 30.88 & 47 & 69.12 & 68 & 100 \\
\hline
\end{tabular}

From the results of the study in table 3 , it was found that almost all $(89.71 \%)$ of the total respondents were at risk (1-4), almost half $(26.47 \%)$ experienced preterm labor and most $(63.24 \%)$ experienced aterm labor. While a small portion $(10.29 \%)$ of the total respondents were at risk (> 4), 3 respondents $(4.41 \%)$ experienced preterm labor and 4 respondents $(5.88 \%)$ experienced aterm labor.
Distribution of Respondents based on ANC Frequency in The Incidence of Preterm Labor

Table 4. Distribution of Respondent based on ANC Frequency in The Incidence of Preterm Labor in Bidan Praktik Mandiri (BPM) Bidan Nanik Suwati, Amd. Keb, Pungging Village, Mojosari Sub-District, Mojokerto District ( $\mathrm{n}=$ 68).

\begin{tabular}{ccccccc}
\hline \multirow{2}{*}{$\begin{array}{c}\text { ANC } \\
\text { Frequency }\end{array}$} & \multicolumn{3}{c}{ Incidence of Preterm Labor } & \multicolumn{2}{c}{ Total } \\
\cline { 2 - 5 } & \multicolumn{2}{c}{ Premature } & \multicolumn{2}{c}{ Aterm } & & \multicolumn{2}{c}{$($ f) } & $(\%)$ & $(\mathrm{f})$ & $(\%)$ & $(\mathrm{f})$ & $(\%)$ \\
\hline $1-3$ & 19 & 27.94 & 29 & 42.65 & 48 & 70.59 \\
$>3$ & 2 & 2.94 & 18 & 26.47 & 20 & 29.41 \\
\hline Total & 21 & 30.88 & 47 & 69.12 & 68 & 100.00 \\
\hline Sources: Primary Data & & & & &
\end{tabular}

From table 4, it was found that most of the 48 respondents $(70.59 \%)$ conducted ANC examinations as much as 1-3 times, 29 respondents $(42.65 \%)$ had preterm labor, and the remaining 19 respondents $(27.94 \%)$ experienced aterm labor. A total of 20 respondents $(29.41 \%)$ conducted an ANC examination of 4 or $>4$ times, a small portion of 2 respondents (2.94\%) experienced preterm labor and 18 respondents (26.47\%) experienced aterm labor.

Distribution of Respondents based on Accompanying Disease in The Incidence of Preterm Labor

Table 5. Distribution of Respondent based on Accompanying Disease in The Incidence of Preterm Labor in Bidan Praktik Mandiri (BPM) Bidan Nanik Suwati, Amd. Keb, Pungging Village, Mojosari Sub-District, Mojokerto District $(n=68)$.

\begin{tabular}{|c|c|c|c|c|c|c|}
\hline \multirow{3}{*}{$\begin{array}{c}\text { Accompanying } \\
\text { Disease }\end{array}$} & \multicolumn{4}{|c|}{$\begin{array}{c}\text { Incidence of Preterm } \\
\text { Labor }\end{array}$} & \multirow{2}{*}{\multicolumn{2}{|c|}{ Total }} \\
\hline & \multicolumn{2}{|c|}{ Premature } & \multicolumn{2}{|c|}{ Aterm } & & \\
\hline & (f) & $(\%)$ & (f) & $(\%)$ & (f) & $(\%)$ \\
\hline $\begin{array}{l}\text { Accompanying } \\
\text { Diseases }\end{array}$ & 0 & 0 & 1 & 1.47 & 1 & 1.47 \\
\hline $\begin{array}{c}\text { No Accompanying } \\
\text { Diseases }\end{array}$ & 21 & 30.88 & 46 & 67.65 & 67 & 98.53 \\
\hline Total & 21 & 30.88 & 47 & 69.12 & 68 & 100.00 \\
\hline
\end{tabular}

From table 5, it was found that a small proportion of 1 respondent $(1.47 \%)$ of the total respondents had a disease that accompanied the pregnancy, but could have aterm labor. While almost all of the 67 respondents $(98.53 \%)$ did not have the disease accompanying pregnancy, 
47 respondents $(69.12 \%)$ experienced preterm labor and the remaining 21 respondents $(30.88 \%)$ experienced aterm labor.

Distribution of Respondents based on Obstetric Complication in The Incidence of Preterm Labor

Table 6. Distribution of Respondent based on Obstetric Complication in The Incidence of Preterm Labor in Bidan Praktik Mandiri (BPM) Bidan Nanik Suwati, Amd. Keb, Pungging Village, Mojosari Sub-District, Mojokerto District $(n=68)$.

\begin{tabular}{|c|c|c|c|c|c|c|}
\hline \multirow{3}{*}{$\begin{array}{c}\text { Obstetric } \\
\text { Complication }\end{array}$} & \multicolumn{4}{|c|}{$\begin{array}{c}\text { Incidence of Preterm } \\
\text { Labor }\end{array}$} & \multicolumn{2}{|c|}{ Total } \\
\hline & \multicolumn{2}{|c|}{ Premature } & \multicolumn{2}{|c|}{ Aterm } & \multirow[b]{2}{*}{ (f) } & \multirow[b]{2}{*}{$(\%)$} \\
\hline & (f) & $(\%)$ & (f) & $(\%)$ & & \\
\hline Obstetric & 0 & 0 & 1 & 1.47 & 1 & 1.47 \\
\hline $\begin{array}{l}\text { Complication } \\
\text { No Obstetric } \\
\text { Complication }\end{array}$ & 21 & 30.88 & 46 & 67.65 & 67 & 98.53 \\
\hline Total & 21 & 30.88 & 47 & 69.12 & 68 & 100.00 \\
\hline
\end{tabular}

From table 6 , it was found that a small portion of 1 respondent $(1.47 \%)$ of the total respondents had obstetric complications, but were able to perform aterm labor. While almost all 67 respondents $(98.53 \%)$ did not have obstetric complications, 47 respondents (69.12\%) experienced preterm labor and the remaining 21 respondents (30.88\%) experienced aterm labor.

The Relationship between Pregnant Women's High-Risk Age with The Preterm of Labor in Bidan Praktik Mandiri (Bpm) Bidan Nanik Suwati, Amd. Keb, Pungging Village, Mojosari Sub-District, Mojokerto District

For this hypothesis test using HI with a significant level of $\alpha<0.05$. From the Chi Square test, it was obtained significant 0.036 . Thus, $\rho=0.036<\alpha=0.05, \mathrm{H} 1$ is accepted, meaning there is a relationship between the high age of pregnant women and the incidence of preterm labor.
Table 7. Examination of The Relationship between Pregnant Women's High-Risk Age with The Preterm of Labor in Bidan Praktik Mandiri (BPM) Bidan Nanik Suwati, Amd. Keb, Pungging Village, Mojosari Sub-District, Mojokerto District $(n=68)$.

\begin{tabular}{|c|c|c|c|c|}
\hline \multicolumn{5}{|c|}{ Chi-Square Tests } \\
\hline & Value & $\mathrm{df}$ & & $\begin{array}{l}\text { Asymp. } \\
\text { Sig. (2- } \\
\text { sided) }\end{array}$ \\
\hline Pearson Chi-Square & $11.869^{\mathrm{a}}$ & & 9 & .036 \\
\hline Likelihood Ratio & 13.601 & & 9 & .137 \\
\hline $\begin{array}{l}\text { Linear-by-Linear } \\
\text { Association }\end{array}$ & 3.282 & & 1 & .070 \\
\hline $\mathrm{N}$ of Valid Cases & 68 & & & \\
\hline
\end{tabular}

a. 16 cells $(80,0 \%)$ have expected count less than 5 . The minimum expected count is, 29 .

Sources: Primary Data

\section{DISCUSSION}

High-Risk Age of Pregnant Women in The Incidence of Preterm Labor

Based on the results of the data tabulation, 68 respondents were at the age of high-risk pregnant women. Almost half (31\%) of respondents experienced preterm labor and most $(69 \%)$ of respondents who experienced aterm labor. From the percentage above shows that the incidence of premature is still high compared to the incidence of preterm labor in Indonesia each year, which is $15-20 \%$ (Manuaba ${ }^{2}$, 1998).

Factors Influencing the Incidence of Preterm Labor, among others:

Characteristic of Respondents based on Parity in The Incidence of Preterm Labor

From the results of the study, it was found that almost all $(89.71 \%)$ of the total respondents were at risk (1-4), almost half (26.47\%) experienced preterm labor and most (63.24\%) experienced aterm labor. While a small portion $(10.29 \%)$ of the total respondents were at risk (> 4), 3 respondents $(4.41 \%)$ experienced preterm labor and 4 respondents (5.88\%) experienced aterm labor.

According to Soetjiningsih (1998), having children more than four increases the risk of mother and baby, such as mothers who often get pregnant at close range can cause mothers too poor due to pregnancy, childbirth, and caring for their children continuously. Another risk is low birth weight babies (premature). 
According to Wiknjosastro (2005), high parity has a high complication of labor, because the more often women experience labor, the vascularization will decrease or atrophy changes occur in the decidua due to the past so that it will harm the health of the fetus. According to Manuaba ${ }^{1}$ (1998), parity at intervals of less than 12 years, the number of pregnancies above four times can be a problem that affects reproduction.

Characteristic of Respondents based on ANC Frequency in The Incidence of Preterm Labor

Based on the results of the study, most of the 48 respondents $(70.59 \%)$ conducted ANC examinations as much as 1-3 times, 29 respondents $(42.65 \%)$ had preterm labor, and the remaining 19 respondents (27.94\%) experienced aterm labor. A total of 20 respondents (29.41\%) conducted an ANC examination of 4 or $>4$ times, a small portion of 2 respondents $(2.94 \%)$ experienced preterm labor and 18 respondents (26.47\%) experienced aterm labor.

According to Manuaba ${ }^{2}$ (1998), antenatal supervision provides benefits by finding various abnormalities that accompany pregnancy early, so that steps can be taken into account and prepared in the delivery assistance. It is known that the fetus in the womb and mother is a unit that influences each other, so that optimal maternal health will improve the health, growth and development of the fetus. Pregnant women are advised to carry out antenatal supervision 4 times.

According to Saifuddin (2002), every pregnant woman faces risks and complications that can threaten her life. Therefore, every pregnant woman requires at least four visits during the antenatal period, i.e. each trimester, while the last trimester is 2 times.

Characteristic of Respondents based on Accompanying Diseases in The Incidence of Preterm Labor

A small proportion of 1 respondent $(1.47 \%)$ of the total respondents had a disease that accompanied the pregnancy, but could have aterm labor. While almost all of the 67 respondents $(98.53 \%)$ did not have the disease accompanying pregnancy, 47 respondents $(69.12 \%)$ experienced preterm labor and the remaining 21 respondents (30.88\%) experienced aterm labor.
According to Manuaba ${ }^{1}$ (1998), pregnancy with complications of maternal disease, such as hypertension, can cause preterm labor.

According to Wiknjosastro (2005), hypertension causes rescuers to tend to terminate pregnancy, this raises the prevalence of increased preterm labor.

Characteristic of Respondents based on Obstetric Complication in The Incidence of Preterm Labor

Based on the results of the study, it was found that a small portion of 1 respondent $(1.47 \%)$ of the total respondents had obstetric complications, but were able to perform aterm labor. While almost all 67 respondents (98.53\%) did not have obstetric complications, 47 respondents $(69.12 \%)$ experienced preterm labor and the remaining 21 respondents (30.88\%) experienced aterm labor.

According to Wiknjosastro (2005), multiple pregnancies will result in excessive uterine distention, thus exceeding the tolerance limit and often causing prematurous parturition. According to Rayburn and Carey (2001), patients at very high risk, such as multiple pregnancies or repeated twins, will increase the threat of preterm labor.

From the discussion above it can be concluded that there are other factors that influence preterm labor, such as parity, ANC frequency, accompanying disease and obstetric complications.

According to Saifuddin (2002), several factors that cause preterm labor are age, parity, marital status, smokers, low socio-economic conditions, hypertension, heart and lung disease, multiple pregnancy, placental abruption, and premature rupture of membranes.

The Relationship between Pregnant Women's High-Risk Age with The Preterm of Labor in Bidan Praktik Mandiri (BPM) Bidan Nanik Suwati, Amd. Keb, Pungging Village, Mojosari Sub-District, Mojokerto District

From the Chi Square test of the research data, it was obtained significant 0.036 . Thus, $\rho$ $=0.036<\alpha=0.05, \mathrm{H} 1$ is accepted, meaning there is a relationship between the high age of pregnant women and the incidence of preterm labor. 
According to Manuaba ${ }^{1}$ (1998), the age of high-risk pregnant women is one of the contributing factors for preterm labor. Pregnant women at high risk age, i.e. under 20 years or more than 35 years, will be at risk of getting complications of pregnancy and childbirth. Pregnancy relatively young from the point of midwifery can cause significant complications (complications), including insufficient labor (prematurity) and imperfect fetal growth in the uterus.

According to Manuaba ${ }^{2}$ (1998), complications in young pregnancies $(<20$ years) are higher than those of healthy reproductive age. This situation is due to immaturity of reproductive organs to become pregnant, so that it can harm maternal health and the development of the fetus.

Pregnancies over the age of 35 years will be at high risk, because at that age women experience a functional decline because they have passed the peak age of 20-35 years. The functional decline of this hormone results in a decrease in body functions, including egg cells so that it can cause preterm labor.

According to Soetjiningsih (1998), pregnancy before the age of 18 years, often results in low-weight babies (premature) and is also at risk for the health of infants and mothers. Likewise, for pregnancy after 35 years of age, because of the risk to the baby.

According to Hidayat, Ajiz, and Krisnadi (2016), pregnant women who are less than 20 years old or more than 35 years old will increase the risk of getting complications of pregnancy and labor as well as their babies.

According to Wiknjosastro (2005), highrisk age the likelihood of a bad pregnancy/ complications will increase such as miscarriage, preterm labor, susceptibility to infection, anemia of pregnancy, hypertension, diabetes mellitus, and obesity.

\section{CONCLUSION}

Based on the results of the study there are several things that can be concluded, among others:

1. From 68 respondents, almost half as many as 21 respondents $(31 \%)$ experienced preterm labor and most of them as many as 47 respondents (69\%) who experienced aterm labor.

2. Factors Influencing the Incidence of Preterm Labor, among others parity,
ANC frequency, accompanying disease and obstetric complications.

3. From the Chi Square test of the research data, it was obtained significant 0.036 . Thus, $\rho=0.036<\alpha$ $=0.05, \mathrm{H} 1$ is accepted, meaning there is a relationship between the high age of pregnant women and the incidence of preterm labor.

\section{SUGGESTION}

Therefore, it should be recommended for mothers as much as possible not to become pregnant at a high-risk age, namely age $<20$ and $>35$ years.

\section{REFERENCES}

Bobak, M. D., \& Jensen, M. D. (2000). Perawatan Maternitas dan Ginekologi. Bandung: YIA-PKP.

Budiarto, E. (2002). Biostatistika Untuk Kedokteran dan Kesehatan Masyarakat. Jakarta: EGC.

Curtis, G. B. (2000). Kehamilan Di Atas Usia 30. Jakarta: EGC.

Davis, J. (2000). Kehamilan Dan Diabetes. Jakarta: Arcan.

Farrer, H. (1999). Perawatan Maternitas. Jakarta: EGC.

Friedman, E. A. (1998). Seri Skema Diagnosis dan Penatalaksanaan Obstetri. Jakarta: Binarupa Aksara.

Hidayat, Z. Z., Ajiz, E. A., \& Krisnadi, S. R. (2016). Risk Factors Associated with Preterm Birth at Hasan Sadikin General Hospital in 2015. Open Journal of Obstetrics and Gynecology, 6(13), 798.

Manuaba, I. B. G 1. (1998). Memahami Kesehatan Reproduksi Wanita. Jakarta: Penerbit Arcan.

Manuaba, I. B. G ${ }^{2}$. (1998). Ilmu Kebidanan, Penyakit Kandungan \& Keluarga Berencana Untuk Pendidikan Bidan. Jakarta: EGC.

Neil-Rose, W. (2007). Panduan Lengkap Perawatan Kehamilan. Jakarta: Dian Rakyat.

Nolan, Mary. (2003). Kehamilan dan Melahirkan. Jakarta: Arcan.

Notoatmodjo, S. (2002). Metodologi Penelitian Kesehatan. Jakarta: Rineka Cipta.

Nursalam. (2003). Konsep \& Penerapan Metodologi Penelitian Ilmu Keperawatan, Pedoman Skripsi, Tesis dan Instrumen 
Penelitian Keperawatan. Jakarta: Salemba Medika.

Oxorn, H. (2003). Patologi dan Fisiologi Persalinan (Human Labor and Birth). Jakarta: Yayasan Essentia Medica.

Rayburn, W. F., \& Carey, J. C. (2001). Obstetri dan Ginekologi. Jakarta: Widya Medika.

Rustam, M. (1998). Sinopsis Obstetri Jilid I. Jakarta: EGC.

Saifuddin, A. B. (2002). Buku Panduan Praktis Pelayanan Kesehatan Maternal dan Neonatal. Jakarta: Yayasan Bina Pustaka Sarwono Prawirohardjo.

Soetjiningsih. (1998). Tumbuh Kembang Anak. Cetakan 2. Jakarta: EGC.

Wiknjosastro, Hanifa. (2005). Ilmu Kebidanan. Jakarta:Yayasan Bina Pustaka Sarwono Prawihardjo.

Cite This Article As: Umami, S. F. \& Idayanti, T. Relationship between Pregnant Women's High-Risk Age with The Preterm of Labor in Bidan Praktik Mandiri (Bpm) Bidan Nanik Suwati, Amd. Keb, Pungging Village, Mojosari Sub-District, Mojokerto District. Nurse and Health: Jurnal Keperawatan 2018; 7(2): 141-147. 